\title{
The Enhancement of Verbal Communication Skills for Vocational Students through Project-Based Learning Physics
}

\author{
Nur Fitri Asih ${ }^{1, a)}$, Ellianawati ${ }^{2}$ \\ ${ }^{1}$ Program Studi Pendidikan Fisika, Pascasarjana Universitas Negeri Semarang, Semarang, Indonesia \\ ${ }^{2}$ Jurusan Fisika, Fakultas MIPA, Universitas Negeri Semarang, Indonesia \\ $\bowtie:{ }^{a)}$ nurfitri.nur7@gmail.com
}

\begin{abstract}
Research has been conducted to enhance the verbal communication skills of vocational students through project-based learning. This study aims to train students' verbal communication skills through project-based learning. The research is a pre-experimental design in the form of a one-shot case study. This research was conducted at Diponegoro Vocational High School in the 2018/2019 school year for students in class X TKR 2 with 33 students. The instruments were observation sheets of oral and written communication skills, worksheets, and documentation. The results showed that the communication skills of Diponegoro Vocational High School students according to indicators of oral communication abilities were can to express opinions and listen to the opinions of others as much as $61.36 \%$, present material of $59.10 \%$, systematically submit report results and cleary $61.36 \%$, asking questions to the teacher or other students for $52.30 \%$, and answer the teacher or other student's questions by $56.37 \%$. While the indicators of writing communication skills can write clear and understandable information at $68.20 \%$, the accuracy of the scientific representation of $52.30 \%$, express the data amounting to 56.82 and use the graphics illustrations $50 \%$. These can conclude that the average percentage of results of oral and written communication skills of students included in the medium category.
\end{abstract}

Keywords: communication skills, verbal communication, project-based learning

\section{INTRODUCTION}

Physics is one of the subjects to support the skills of the competence majors in vocational schools. It is considered necessary for training taught useful thinking skills to solve problems in everyday life (Fadly et al., 2014). One of the core competencies is to planning the experiments, carry out the method according to the rules of physics experiments, and communicate the results of the experiment. According to Sumaryanta (2008), communication is one of the primary process skills that should be owned by every student in learning physics. Such skills can be nurtured, trained, even developed through learning activities in schools (Putri et al., 2017).

The communication skills must be possessed child to face the challenges of the 21 st century. Learning to communicate is the key to the child to interact with the people in the world and to meet their needs known (Oktavianingsih, 2017). According to Yore, Pimm \& Master (2007), communication can facilitate the construction of understanding, persuasion, and sharing of ideas is an essential goal of science education reforms and promotes science literacy. Purposeful discussion in 
inquiry activities can enhance learning for understanding and the development of scientific discourse (Chang et al., 2010).

Communication skills play an essential role in learning physics because it can change the learning situation to the better with emerging social interaction between students and students-teachers (Pandu et al., 2017). Communication is the process of sending messages or information from the communicator (person who sends a message to the communicant) (person receiving the message) (Choiriyah et al., 2014). Verbal communication is a two-step process between speakers and listeners involves the productive skills of speaking and receptive skills in comprehension (Alam et al., 2013). Verbal communication skills in learning physics students can be trained through learning that provoke students to active learning, one of them with project-based learning.

Project-based learning is an in-depth investigation of a topic. This investigation can be undertaken by a small group of children within a class, sometimes by a whole class, and occasionally by an individual child. It means that project-based learning is a learning method that explores a particular topic that is learned by children individually or in groups (Nurhalimah 2012). The previous study, implementation of project-based learning can enhance the understanding of students (Serevina 2015).

The consistency with constructivist perspectives on teaching and learning, empirical evidence indicates that effective communication practices are those that trigger and perpetuate in-depth cognitive elaboration of the learning material, thus allowing students to progressively build, rearrange, refine and revise their conceptions of the topics concerned (Kärner et al., 2015). Verbal communication skills to train students to think, ask, present the results of scientific discussions either orally or in writing. However, in reality, students' ability to communicate is very less. So that students are often passive in asking, argue, and present their thoughts in a systematic and precise. Research carried out previously by Putri A. et al. (2016), that the oral communication skills of students only reached $56.18 \%$, while the students' communication skills reached $61.06 \%$. Therefore it is necessary to do further research on the verbal communication skills of students in learning physics through project-based learning to train students verbal communication skills.

\section{RESEARCH METHODOLOGY}

This study uses a pre-experimental design form a one-shot case study in one study group. The research was conducted at SMK Diponegoro Lebaksiu academic year 2018/2019. The research sample is class X TKR 2, with 33 students. The sampling technique in this study using techniques cluster random sampling, i.e. taking a batch of it random. The instrument used to collect data that student observation sheets, worksheets, and documentation.

The student observation data obtained from observation sheets aspects of communication skills for oral communication skills, which are used for direct observation on the activities of the project results presentation, and student observation sheet to aspects of communication skills in writing, which is used to measure a written communication in the project report.

The indicators of oral communication skills, as measured in previous studies, belong to Oktaviani et al. (2015) described in TABLE 1. The indicators of written communication skills measured in previous studies by Putri et al. (2015) described in TABLE 2. Data on students' communication skills obtained through the observation sheet were analyzed in percentage to determine oral and written communication skills. The analysis used is descriptive. The formulation of communication skills assessment in the previous study of Putri et al. (2015) described in TABLE 3.

communication skills score $=\frac{\text { scores obtained by students }}{\text { maximum score }} \times 100 \%$ 
TABLE 1. Oral Communication Capability Indicator

\begin{tabular}{|c|c|c|}
\hline Indicator & Score & Explanation \\
\hline \multirow{4}{*}{$\begin{array}{l}\text { Able to express opinions } \\
\text { and listen to the } \\
\text { opinions of others }\end{array}$} & 1 & Unable to express opinions and listen to the opinions of others \\
\hline & 2 & $\begin{array}{l}\text { Less able to express opinions and listen to the opinions of } \\
\text { others }\end{array}$ \\
\hline & 3 & Able to express opinions and listen to the opinions of others \\
\hline & 4 & $\begin{array}{l}\text { Very able to express opinions and listening to the opinions of } \\
\text { others }\end{array}$ \\
\hline \multirow{4}{*}{$\begin{array}{l}\text { Able to master the } \\
\text { material that will be } \\
\text { used as presentation } \\
\text { material }\end{array}$} & 1 & $\begin{array}{l}\text { Unable to master the material that will be used as presentation } \\
\text { material }\end{array}$ \\
\hline & 2 & $\begin{array}{l}\text { Less able to master the material that will be used as } \\
\text { presentation material }\end{array}$ \\
\hline & 3 & $\begin{array}{l}\text { Able to master the material that will be used as presentation } \\
\text { material }\end{array}$ \\
\hline & 4 & $\begin{array}{l}\text { Very able to master the material that will be used as } \\
\text { presentation material }\end{array}$ \\
\hline \multirow{4}{*}{$\begin{array}{l}\text { Able to deliver report } \\
\text { results systematically } \\
\text { and clearly }\end{array}$} & 1 & Unable to deliver report results systematically and clearly \\
\hline & 2 & Less able to deliver report results systematically and clearly \\
\hline & 3 & Able to deliver report results systematically and clearly \\
\hline & 4 & Very able to deliver report results systematically and clearly \\
\hline \multirow{4}{*}{$\begin{array}{l}\text { Dare to ask the teacher } \\
\text { or other students }\end{array}$} & 1 & Do not dare to ask the teacher or other students \\
\hline & 2 & Less brave to ask the teacher or other students \\
\hline & 3 & Dare to ask the teacher or other students \\
\hline & 4 & Very brave to ask the teacher or other students \\
\hline \multirow{4}{*}{$\begin{array}{l}\text { Able to answer teacher } \\
\text { or other student } \\
\text { questions }\end{array}$} & 1 & Unable to answer teacher or other student questions \\
\hline & 2 & $\begin{array}{l}\text { Less able to answer the questions of the teacher or other } \\
\text { students }\end{array}$ \\
\hline & 3 & Able to answer teacher or other student questions \\
\hline & 4 & $\begin{array}{l}\text { Very able to answer the questions of the teacher or other } \\
\text { students }\end{array}$ \\
\hline
\end{tabular}

TABLE 2. Written Communication Capability Indicator

\begin{tabular}{lll}
\hline Indicator & Score & Explanation \\
\hline Able to write clear and & 1 & Unable to write clear and understandable information \\
understandable & 2 & Less able to write clear and understandable information \\
information & 3 & Able to write clear and understandable information \\
& 4 & Very able to write clear and understandable information \\
The accuracy of & 1 & Scientific representation is not appropriate \\
representation & 2 & Scientific representation is less appropriate \\
scientifically & 3 & Scientific representation is appropriate \\
& 4 & Scientific representation is very appropriate \\
Able to express data & 1 & Unable to express data clearly \\
clearly & 2 & Less able to express data clearly \\
& 3 & Able to express data clearly \\
& 4 & Very able to express data clearly \\
Able to use & 1 & Unable to use understandable illustrations \\
understandable & 2 & Less able to use understandable illustrations \\
illustrations & 3 & Able to use understandable illustrations \\
& 4 & Very able to use understandable illustrations \\
\hline
\end{tabular}


TABLE 3. Student Communication Ability Criteria

\begin{tabular}{ll}
\hline The percentage obtained $(\mathbf{x})$ & Criteria \\
\hline $80 \%<\mathrm{x}$ & Very high \\
$60 \%<\mathrm{x} \leq 80 \%$ & High \\
$40 \%<\mathrm{x} \leq 60 \%$ & Medium \\
$20 \%<\mathrm{x} \leq 40 \%$ & Low \\
$\mathrm{x} \leq 20 \%$ & Very low \\
\hline
\end{tabular}

\section{RESULTS AND DISCUSSION}

This research was conducted at Diponegoro Lebaksiu Vocational School in TKR 2 class X, with a total of 33 students being male students. This learning has used the 2013 curriculum, where projectbased learning is recommended in the 2013 curriculum that requires students to produce contextual work and facilitates students to communicate their work to the community (Fadly et al., 2014). Project-based learning helps students develop real-world abilities to collaborate, make decisions and initiatives, overcome complex problems, communication, and self-regulation, and can improve memory (Yalcin et al., 2009).

Learning is done in groups in order to bring out communication aspects and cause changes in student attitudes in learning. Each group consists of three students to discuss. The purpose of establishing a small number of groups is so that learning can be conducive. This learning is assisted by Macromedia Flash to facilitate students in discussion and question and answer that can trigger communication between students and students and teachers and students. Learning begins with the teacher giving the material to students in the form of question and answer physical problems related to the subject matter of the collision. Students are given two projects in the learning in the form of student worksheets (SW) containing collision case questions that students must discuss with their groups then presented and concept map projects or mind mapping that students must make together with their discussion groups. Giving two projects, namely SW and concept maps, is to explore students' verbal communication skills, both oral and written communication.

The presentation activities and concept map making are documented in FIGURE 1.

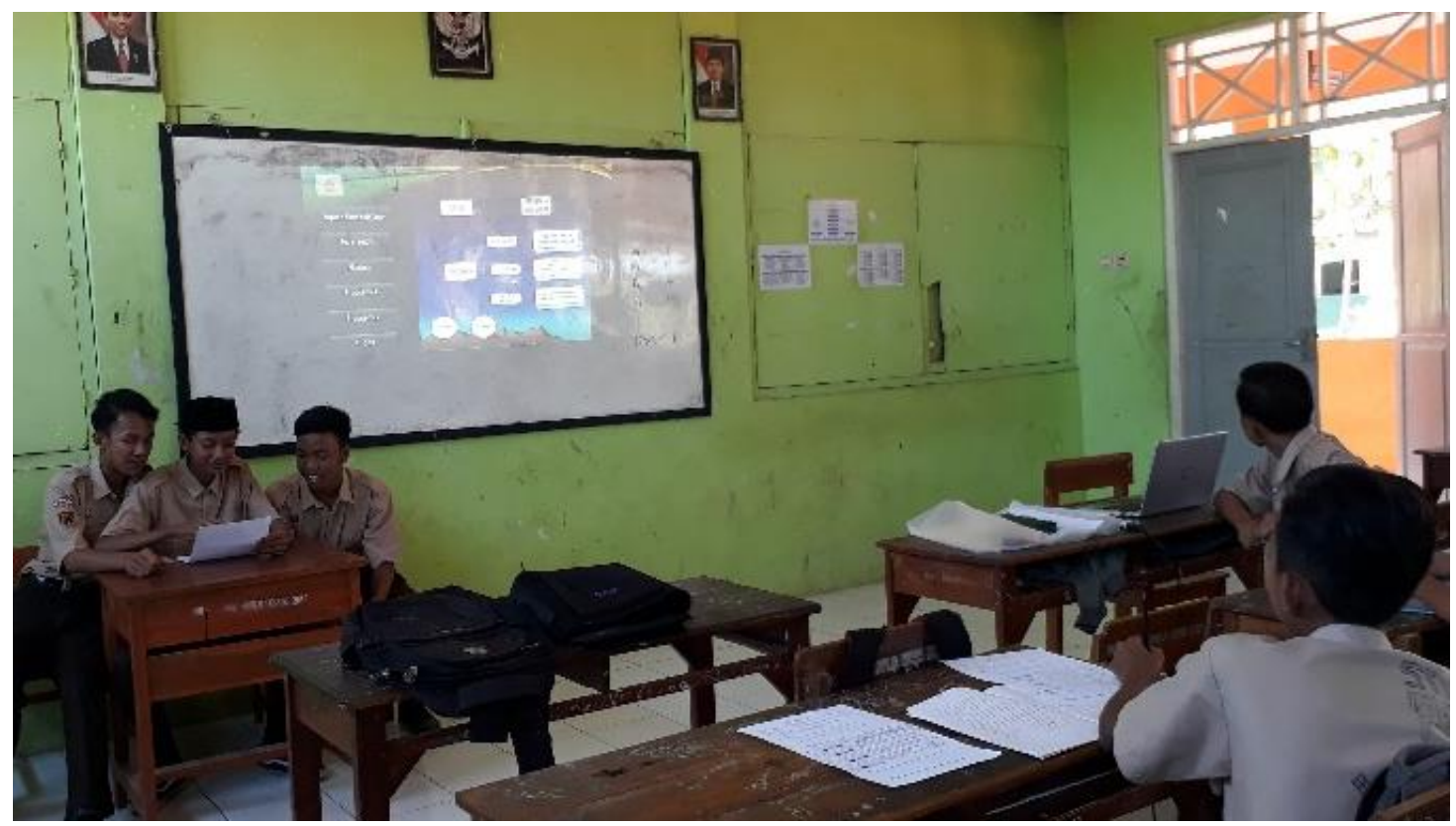

(a) 


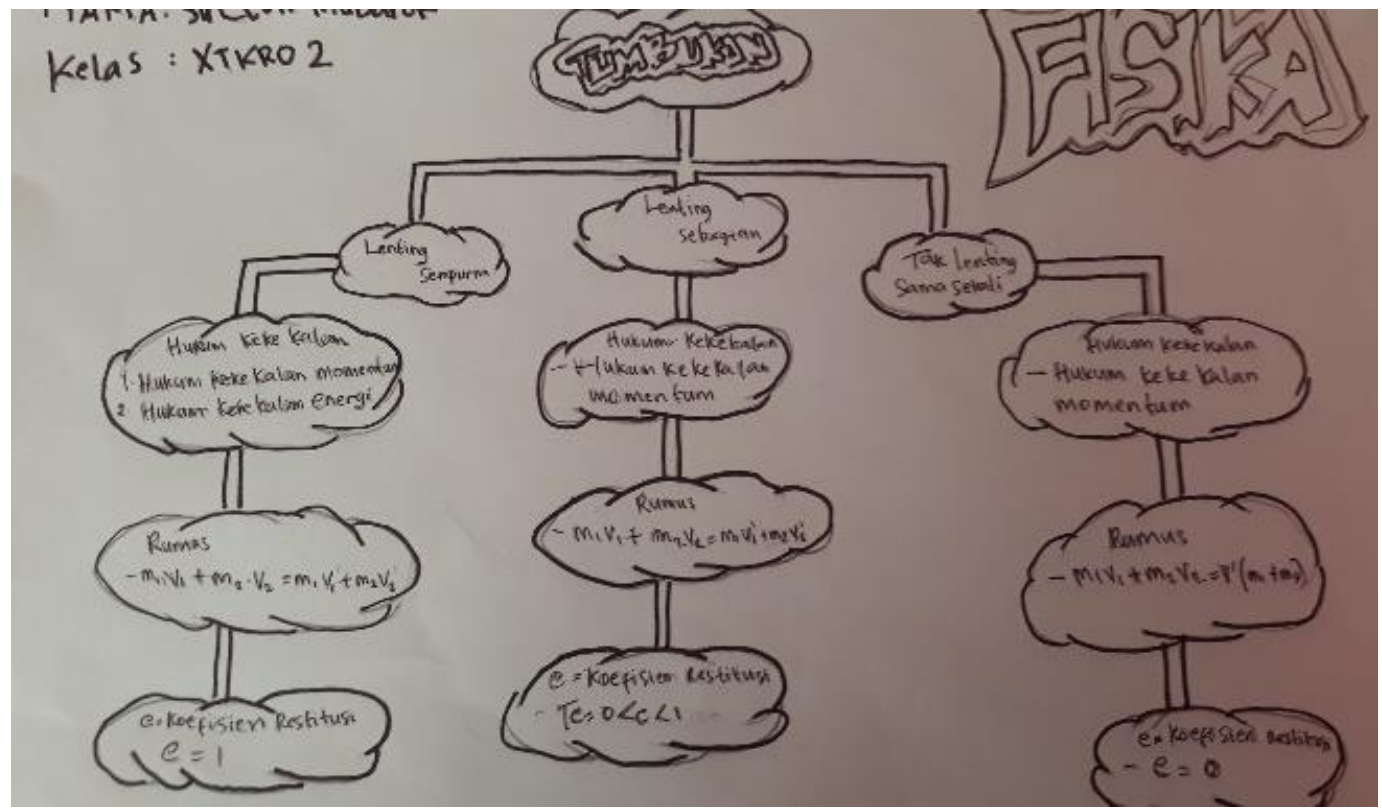

(b)

FIGURE 1. (a) Students when presenting the results of SW discussions in front of the class, (b) the work of student concept maps.

Research students' verbal communication skills consist of two aspects, namely oral communication skills and written communication skills.

\section{Oral communication skills}

Analysis of oral communication skills of students includes being able to express opinions and listen to the opinions of others, master the material, be able to deliver the results of the report systematically, able to ask and be able to answer questions. Based on the presentation of each group, the data obtained in FIGURE 2 follows:

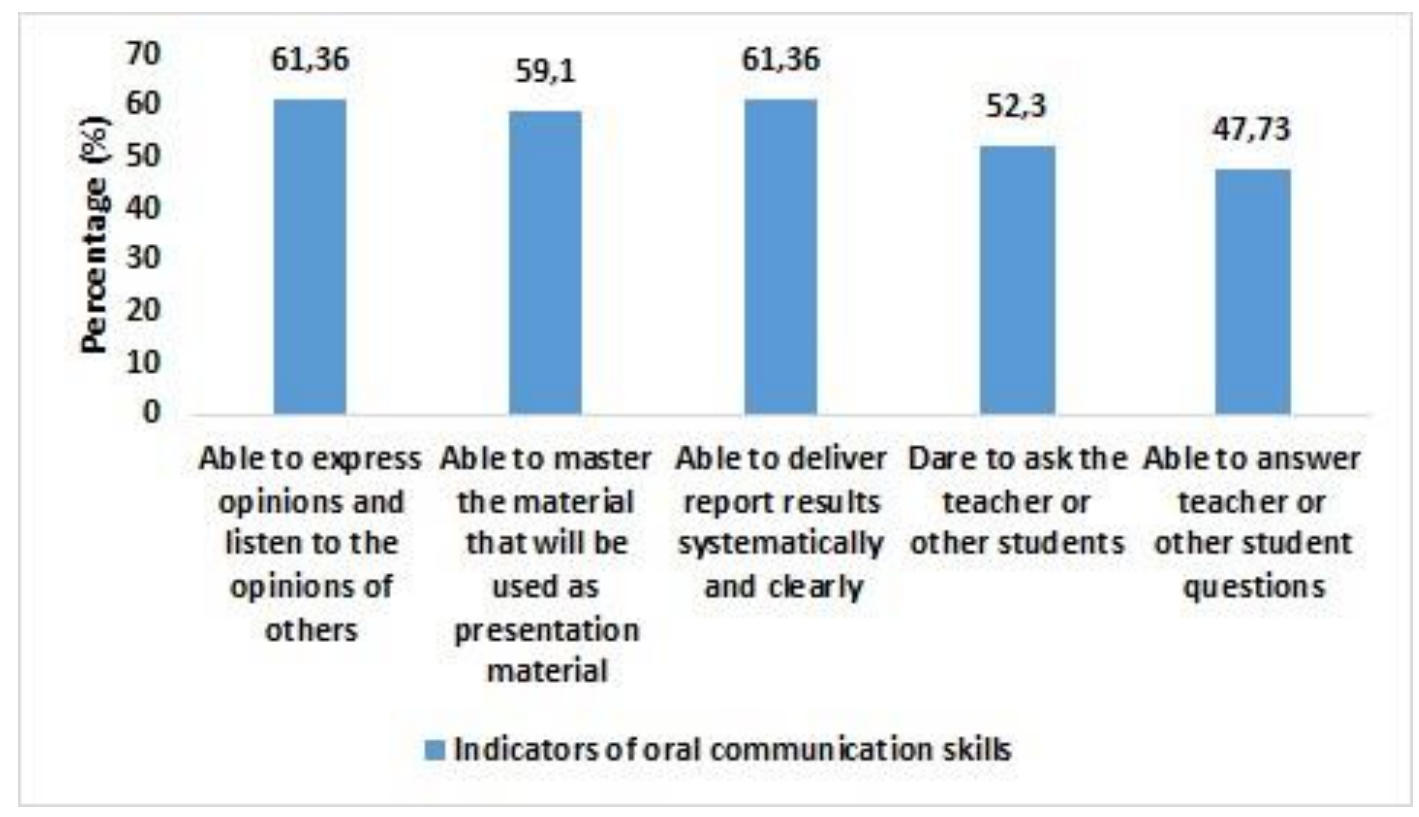

FIGURE 2. Oral Communication Ability 
Based on the results of data analysis in FIGURE 2, it can be seen that the highest indicator of oral communication skills of class X TKR 2 students at SMK Diponegoro Lebaksiu can express opinions and listen to the opinions of others, and be able to deliver report results systematically and clearly in high categories. The lowest indicator of oral communication skills of students can answer a teacher or other students' questions in the medium category. The lowest indicator is seen when the teacher asks; students do not respond to the question. There are still many students who, when discussing, lack confidence in asking or answering given by the teacher or other students. Based on these descriptions, the average percentage of indicators of students' oral communication skills is $56.37 \%$ with a moderate category.

\section{Writing communication skills}

Analysis of students' writing communication skills include being able to write information, the accuracy of representation scientifically, being able to express data, and being able to illustrate. Based on the results of each group's project, the data obtained in FIGURE 3 follows:

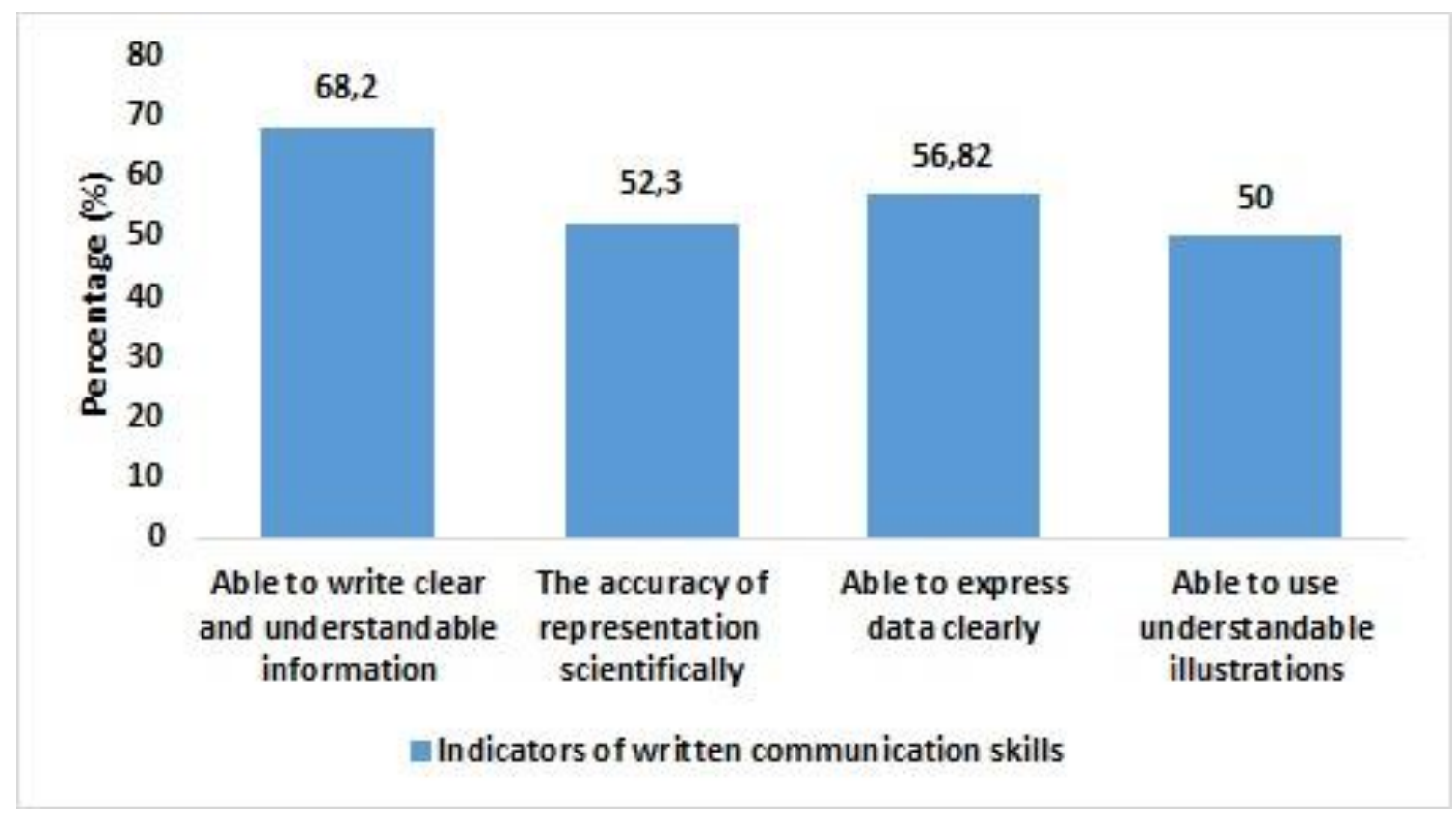

FIGURE 3. Writing Communication Skills

Based on the results of data analysis in FIGURE 3, it can be seen that the highest indicator of writing communication skills of class X TKR 2 students at SMK Diponegoro Lebaksiu can write clear and understandable information in high categories. The lowest indicator of oral communication skills of students can use illustrations that can be understood in the medium category. The lowest indicator is seen when students are asked to make a concept map; initially, students still experience confusion in illustrating the material being taught. Based on the description, the average percentage of students' writing communication skills indicators is $56.82 \%$ with the medium category.

The Previous research by Oktaviani et al (2015), explained that students 'communication skills in making reports on phenetic analysis which is written communication skills had an average percentage of $56.25 \%$ with sufficient categories and students' ability to present the results of phenetic analysis which constituted communication skills verbally had a presentation of $63.75 \%$ with sufficient categories.

The average percentage of the verbal ability of Diponegoro Vocational High School students as a whole between oral and verbal was $56.60 \%$ with the medium category. The verbal communication ability of Diponegoro Vocational High School students based on the analysis of data obtained, both 
oral communication skills and written communication skills still need to be trained independently so that students' verbal communication skills can be explored to the fullest.

\section{CONCLUSIONS}

Based on the results of the above research, it was obtained that the average score of the indicator for verbal communication skills was categorized as medium. The results of the average indicator score for students' communication skills are also categorized as being moderate. Thus, it can be concluded that the communication skills of class X TKR 2 students at SMK Diponegoro Lebaksiu can be trained through the application of project-based learning.

For further research, optimal results will be obtained if students can be trained by applying other learning methods that are more suitable by the conditions of students to improve students' verbal communication skills.

\section{REFERENCES}

Alam, Q \& Uddin, A B 2013, 'Improving English Oral Communication Skills of Pakistani Public School's Students,' Internasional Journal of English Language Teaching, vol. 1, no. 2, pp. 17-36.

Altun Yalçin, S, Turgut, Ü, \& Büyükkasap, E, 2009, 'Proje Tabanlı Öğretim Yönteminin Öğrencilerin Elektrik Konusu Akademik BaŞarılarına, Fiziğe KarŞı Tutumları na ve Bilimsel İŞlem Becerilerine Etkisinin İncelenmesi,' International Online Journal of Educational Sciences, vol. 1, no. 1.

Chang, H P, Chen, C C, Guo, G J, Cheng, Y J, Lin, C Y \& Jen, T H 2011, 'The development of a competence scale for learning science: Inquiry and communication,' International Journal of Science and Mathematics Education, vol. 9, no. 5, pp. 1213-33.

Choiriyah, S, Samidi \& Rukayah 2014, 'Upaya Meningkatkan Kemampuan Berkomunikasi Lisan melalui Metode Bermain Peran Pada Anak Kelompok B TKIT Nur Hidayah Surakarta Tahun Ajaran 2013/2014,' UNS-FKIP Jur. Ilmu Pendidikan-X.8110539-2014.

Fadly. W \& Mubarak, F A 2014, 'Kajian Teoritis Model Productive: Suatu Model Pembelajaran Fisika Berbasis Proyek yang Dikembangkan melalui Kegiatan Komunikatif,' Jurnal Prosiding Pendidikan Sains IV, FKIP Universitas Sebelas Maret, Surakarta, vol 1, no. 1.

Kärner, T, \& Warwas, J 2015, 'Functional Relevance of Students' Prior Knowledge and Situational Uncertainty during Verbal Interactions in Vocational Classrooms: Evidence from A MixedMethods Study, Empirical Research in Vocation Education and Training,' a Spinger Open Journal, vol. 7, no. 11, pp. 1-26.

Nurhalimah, V 2012, 'Pengaruh Metode Proyek Terhadap Kemampuan Kerjasama Anak Usia Dini Kelompok B di RA Perwanida 03 Mojo Andong Boyolali Tahun Pelajaran 2011/2012', Skripsi, Surakarta: Universitas Muhammadiyah Surakarta.

Oktaviani, F \& Hidayat, T 2015, 'Profil Keterampilan Berkomunikasi Siswa SMA Menggunakan Metode Fenetik dalam Pembelajaran Klasifikasi Arthropoda,' Jurnal Pengajaran MIPA, vol. 15, no. 1, pp. 13-24.

Oktavianingsih, E 2017, 'Meningkatkan Keterampilan Berkomunikasi Verbal Anak Usia Dini melalui Pembelajaran Berbasis Proyek,' KMP Education Research Conference, Yogyakarta.

P, Pandu G W, Suyana, I, Amalia, L \& Setiawan, A 2017, 'Upaya Meningkatkan Kemampuan Komunikasi dan Pemahaman Konsep Siswa melalui Pembelajaran Inkuiri Berbantuan Teknik TSTS (Pada Materi Gerak Lurus di SMAN 6 Bandung),' Jurnal Wahana Pendidikan Fisika, vol. 2, no. 2, pp. 27-31.

Putri, A, Enawaty, E \& Lestari, I 2016, 'Deskripsi Keterampilan Komunikasi Siswa SMA Negeri 9 Pontianak Melalui Metode Praktikum pada Materi KSP,' Jp Pendidikan dd 2016. 
Putri, M D, Yennita, \& Nor, M 2015, 'Kemampuan Berkomunikasi Siswa Melalui Penerapan Strategi Pembelajaran Berbasis Proyek di Kelas XI SMA Babussalam Pekanbaru,' Jurnal Online Mahasiswa, vol. 2, no. 2, pp. 1-11.

Serevina, V \& Muliyati, D, 2015, 'Peningkatan Hasil Belajar Siswa pada Materi Dinamika Gerak

Partikel Dengan Menerapkan Model Pembelajaran Project Based Learning. Jurnal Penelitian \& Pengembangan Pendidikan Fisika, 1(1), 61-68. 